\title{
Keragaman Morfologi dan Analisis Kekerabatan Anggrek Phalaenopsis Spesies dan Hybrid
}

\author{
Morphology Diversity and Relationship Analysis of Phalaenopsis Species and \\ Hybrid
}

\author{
Lita Rahmadani, Aziz Purwantoro*)
}

\begin{abstract}
Departemen Budidaya Pertanian, Fakultas Pertanian, Universitas Gadjah Mada Jalan Flora No. 1, Bulaksumur, Sleman, Yogyakarta 55281, Indonesia.

*Penulis untuk korespondensi Email: ronsasm@hotmail.com
\end{abstract}

\begin{abstract}
Creating a new variety of Phalaenopsis orchids needs certain characteristics of parents that in line with market demand. The success of the creation is determined by relationship of orchids that utilized as the parents, so morphology characterization was needed to conduct. Characterization of hybrid orchids morphology is needed to find and differentiate the orchid's morphological appearance. The objective was to determine the diversity of morphology from Phalaenopsis spesies and hybrid based on Shanon Index value and the relationship based on similiarities value. The research was conducted in three orchids gardens in Yogyakarta, namely Balelawang, Titi Orchids, and Kebun Anggrek Mas Jogja. This research used descriptive observational method that was direct observation in the field to fifteen accessions of Phalaenopsis Orchids based on Characterization Guidance of Anggrek from Balai Tanaman Hias. Observation result for the orchid's morphology and flower shape was converted to binary data. Determination of diversity was known through Shanon Index calculation and relationship was known by using software Numerical Taxonomy and Multivariate Analysis System (NTYSYS) Spc 21. Based on morphology character of all sample from this research showed the Shanon Index value as 2.70 who classified to middle diversity. The relationship on Phalaenopsis spesies and hybrid was distributed in two cluster with the similarity value of 0.48 .
\end{abstract}

Keywords: Characterization, hybrid, Phalaenopsis, shanon index, species

\section{INTISARI}

Perakitan varietas baru anggrek dari Phalaenopsis memerlukan tetua dengan sifat tertentu yang disesuaikan dengan permintaan pasar. Keberhasilan perakitan varietas baru ditentukan oleh hubungan kekerabatan antar anggrek yang digunakan sebagai tetua sehingga diperlukan karakterisasi. Karakterisasi morfologi anggrek hybrid juga diperlukan untuk menentukan dan membedakan penampakan morfologi antar anggrek. Tujuan penelitian yaitu untuk menentukan keragaman morfologi anggrek Phalaenopsis spesies dan hybrid berdasarkan nilai Indeks Shanon dan menentukan hubungan kekerabatan berdasarkan nilai similaritasnya. Penelitian dilakukan di tiga kebun anggrek yang ada di Yogyakarta yaitu Kebun Anggrek Balelawang, Titi Orchids, dan Kebun Anggrek Mas Jogja. Penelitian ini menggunakan metode observasional deskriptif yaitu pengamatan 
langsung di lapangan terhadap lima belas anggrek Phalaenopsis berdasarkan Panduan Karakterisasi Anggrek dari Balai Tanaman Hias. Hasil pengamatan morfologi tanaman dan bentuk bunga anggrek diubah menjadi data biner. Penentuan keragaman diketahui melalui perhitungan Indeks Shanon dan hubungan kekerabatanya diketahui menggunakan software Numerical Taxonomy and Multivariate Analysis System (NTYSYS) Spc 21. Berdasarkan karakter morfologinya menunjukkan nilai Indeks Shanon sebesar 2,70 yang diklasifikasikan dalam keragaman sedang. Hubungan kekerabatan Phalaenopsis spesies dan hybrid membentuk dua kelompok dengan nilai similiaritasnya 0,48 .

Kata kunci: Hybrid, indeks shanon, karakterisasi, Phalaenopsis, spesies

\section{PENDAHULUAN}

Anggrek merupakan salah satu tanaman hias dengan tingkat keragaman spesies yang tinggi dan telah menghasilkan berbagai pola diferensiasi genetik antar populasinya (Niknejad et al., 2009). Menurut Parnata (2005), bahwa kegiatan budidaya anggrek memiliki nilai ekonomis tinggi karena keunikan bunganya. Bunga anggrek memiliki variasi bentuk dan warna yang berbeda dengan tanaman hias lainnya serta daya tahan bunga yang lama. Selain itu, anggrek juga memiliki labellum dengan bentuk dan warna yang juga bervariasi antar spesiesnya. Labellum ini dapat digunakan sebagai salah satu penentu jenis anggrek.

Keragaman anggrek di Indonesia sangat tinggi sehingga dikenal sebagai megadiversity anggrek dunia. Pada saat ini, beberapa populasi anggrek terancam punah karena bencana alam dan alih fungsi areal hutan terutama di Jawa yang terkonversi menjadi pemukiman atau perkebunan. Selain itu, pedagang anggrek yang secara illegal memanen di alam tanpa diikuti dengan teknik budidaya yang tepat, sehingga populasi anggrek semakin menurun (Puspitaningtyas, 2005 cit. Hartati dan Darsana, 2015). Perlu adanya kegiatan budidaya yang tepat untuk melestarikan anggrek dan program pemuliaan tanaman untuk mempertahankan keberadaan anggrek sebagai sumber gen dan meningkatkan keragaman anggrek yang ada di Indonesia.

Salah satu program pemuliaan tanaman yang dapat meningkatkan keragaman genetik anggrek adalah persilangan. Hasil persilangan akan menghasilkan berbagai anakan anggrek baru dengan sifat unggul yang dikehendaki. Hal ini memerlukan informasi karakter morfologi anggrek untuk proses pembentukan anggrek hibrid dengan sifat unggul sesuai harapan pemula. Salah satu jenis anggrek yang sering disilangkan adalah anggrek Phalaenopsis atau dikenal sebagai anggrek bulan. Phalaenopsis hybrid sudah banyak dipasarkan tetapi tidak semua tanaman yang dijual diberi label nama varietas. Ada beberapa tipe hybrid yang banyak ditemukan yaitu hybrid berbunga putih, 
bunga kuning atau bunga merah muda hingga merah tua (Pangestu et al., 2014). Keragaman yang tinggi pada Phalaenopsis spesies dan hybrid memerlukan adanya penanda morfologi yang dapat membedakan antar jenis anggrek.

Pada anggrek, karakter morfologi daun dan bunga merupakan karakter yang digunakan sebagai penanda morfologi untuk membedakan antar jenis anggrek. Bunga digunakan sebagai penanda dalam membedakan spesies anggrek dalam satu genus, karena variasi morfologi terdapat pada bunga (Purwantoro et al., 2005). Dengan adanya keragaman anggrek yang cukup tinggi di Indonesia khususnya anggrek Phalenopsis maka karakterisasi secara morfologi perlu dilakukan agar mengetahui karakter dan keunikan yang dimiliki oleh setiap spesies anggrek dan hubungan kekerabatannya. Karakterisasi dilakukan berdasarkan Panduan Karakterisasi Anggrek (Balithi, 2007).

\section{BAHAN DAN METODE}

Penelitian ini dilaksanakan di tiga kebun anggrek yang ada di D.I. Yogyakarta yaitu Kebun Anggrek Balelawang yang berlokasi di Tegalsan, Umbulharjo, Cangkringan, Sleman, kemudian Titi Orchids yang berlokasi di Tebonan, Pakem, Sleman, dan Kebun Anggrek Mas Jogja yang berlokasi di Manukan, Condongcatur, Depok, Sleman. Penelitian dilaksanakan pada bulan Oktober 2018 - Januari 2019. Alat yang digunakan yaitu benang, penggaris, jangka sorong, meteran, alat tulis, clipboard, panduan deskriptor anggrek, form deskripsi, dan kamera digital. Bahan yang digunakan adalah anggrek spesies dan anggrek hybrid berdasarkan koleksi dari ketiga kebun tersebut. Terdapat 10 anggrek spesies yaitu Phal. pantherina, Phal. belina, Phal. corningiana, Phal. inscripstiosinensis, Phal. javanica, Phal. amabilis, Phal. fuscata, Phal. gigantea, Phal. amboinensis, Phal. violaceae dan 5 anggrek hybrid yaitu Phal. Hybrid 1, Phal. Hybrid 2, Phal. Hybrid 3, Phal. Hybrid 4, dan Phal. Hybrid 5 yang digunakan dalam penelitian ini. Penelitian menggunakan metode observasional deskriptif untuk mengetahui keragaan anggrek secara morfologi. Karakterisasi pada anggrek dilakukan terhadap 3 tanaman dan dijadikan sebagai ulangan dengan memilih tanaman dengan kenampakan morfologi baik. Pengamatan karakter morfologi terdiri dari karakter kualitatif dan kuantatif morfologi tanaman dan bunga yang berdasarkan panduan karakterisasi anggrek dari Balai Penelitian Tanaman Hias.

Penentuan tingkatan keragaman diketahui melalui perhitungan indeks keragaman menggunakan rumus Shanon - Wiener (Fachrul, 2008) yaitu: 


$$
\mathrm{H}^{\prime}=-\sum_{i=1}^{n} \mathrm{pi} \text { In pi }
$$

Keterangan:

$H^{\prime}=$ Indeks Keragaman Shanon- Wiener

$p i=\mathrm{ni} / \mathrm{N}$

$\mathrm{ni}=$ Jumlah sampel individu tiap spesies ke-i

$\mathrm{N}=$ Total sampel tanaman yang diamati

Fachrul (2008) menyatakan terdapat tiga klasifikasi tingkat keragaman berdasarkan Indeks keragaman Shanon - Wiener yaitu (i) $\mathrm{H}^{\prime}<1$, berarti keragaman rendah, (ii) $1<\mathrm{H}^{\prime}$ $<3$, berarti keragaman sedang, dan (iii) $\mathrm{H}^{\prime}>3$, berarti keragaman tinggi.

Kekerabatan didasarkan atas nilai similaritas dari karakter kualitatif tanaman dan bunga anggrek untuk masing-masing genus. Data pengamatan diubah menjadi data skor. Penentuan skor data kualitatif berdasarkan tabel dekriptor yang telah disediakan oleh Balai Penelitian Tanaman Hias. Selanjutnya data skor diubah menjadi data biner yang terdiri dari nilai 1 dan 0 . Nilai 1 menunjukkan adanya karakter tertentu pada anggrek, sementara nilai 0 menunjukkan tidak adanya karakter tertentu dan dikomputasikan menggunakan software Numerical Taxonomy and Multivariate Analysis System (NTYSYS) Spc 21 hingga diperoleh dendrogram hubungan kekerabatan.

\section{HASIL DAN PEMBAHASAN}

Karakterisasi morfologi Phalaenopsis spesies dan hybrid dilakukan pada karakter umum, daun, dan bunga. Pada setiap karakter terdapat beberapa sub karakter yang mana dalam penelitian ini terdapat 55 sub karakter pengamatan. Anggrek Phalaenopsis spesies memiliki keragaman yang lebih tinggi dibandingkan Phalaenopsis hybrid. Hal ini dikarenakan Phalaenopsis hybrid merupakan hasil persilangan para pemulia dengan menggabungkan sifat yang sesuai dan diseleksi hingga ditemukan anggrek hybrid yang memenuhi standar atau kriteria pasar. Persamaan antar asesi Phalaenopsis hybrid disebabkan oleh kesamaan sifat genetik pada masing-masing asesi sedangkan perbedaan pada beberapa sifat disebabkan oleh perubahan lingkungan seperti, nutrisi, suhu, kelembaban, dan iklim (Hardiyanto et al., 2007). Karakterisasi yang dilakukan pada karakter umum anggrek Phalaenopsis spesies dan hybrid menunjukkan perbedaan yang tidak berbeda nyata sehingga perlu dilakukan pengamatan karakter lebih lanjut seperti karakter daun dan bunganya. Semakin banyak karakter yang diamati 
maka semakin akurat data yang diperoleh. Hasil pengamatan tersebut dapat digunakan untuk mengetahui keragaman dan hubungan kekerabatan antar anggreknya. Semakin tinggi keragaman anggrek maka semakin bervariasi anggrek hybrid yang dihasilkan saat persilangan. Dengan adanya karakterisasi maka mempermudah pemulia dalam memilih karakter morfologi yang diinginkan. Hubungan kekerabatan juga mempengaruhi tingkat keberhasilan persilangan anggrek. Semakin dekat hubungan kekerabatan tetua anggrek, maka semakin besar peluang berhasilnya persilangan.

\section{Indeks Shanon Phalaenopsis spesies dan hybrid}

Indeks Shanon diperlukan untuk memberikan gambaran mengenai keragaman yang ada pada suatu populasi anggrek yang diamati. Nilai Indeks Shanon menunjukkan keragaman pada setiap sub karakter. Nilai indeks tersebut menunjukkan keragaman rendah, sedang ataupun tinggi. Nilai Indeks Shanon tergantung pada sub karakter morfologi yang diamati dalam suatu populasi. Pada karakter dengan variasi morfologi yang tinggi maka nilai Indeks Shanon juga tinggi sehingga tingkat keragamannya tinggi. Selain itu, nilai tersebut tergantung pula pada jumlah individu tanaman yang diamati. Semakin banyak individu tanaman yang diamati dalam suatu populasi maka tingkat keberagamannya tinggi. Nilai Indeks Shanon sebasar nol menunjukkan tidak adanya keragaman atau penampakan morfologi yang sama pada semua anggrek dalam populasi tersebut. Selain itu, beberapa sub karakter memiliki kenampakkan yang sudah pasti muncul untuk setiap generasinya, sebagai contoh pertumbuhan monopodial Phalaenopsis selalu dimiliki oleh semua jenis anggrek tersebut. 
Tabel 1. Indeks Shanon Phalaenopsis spesies dan hybrid

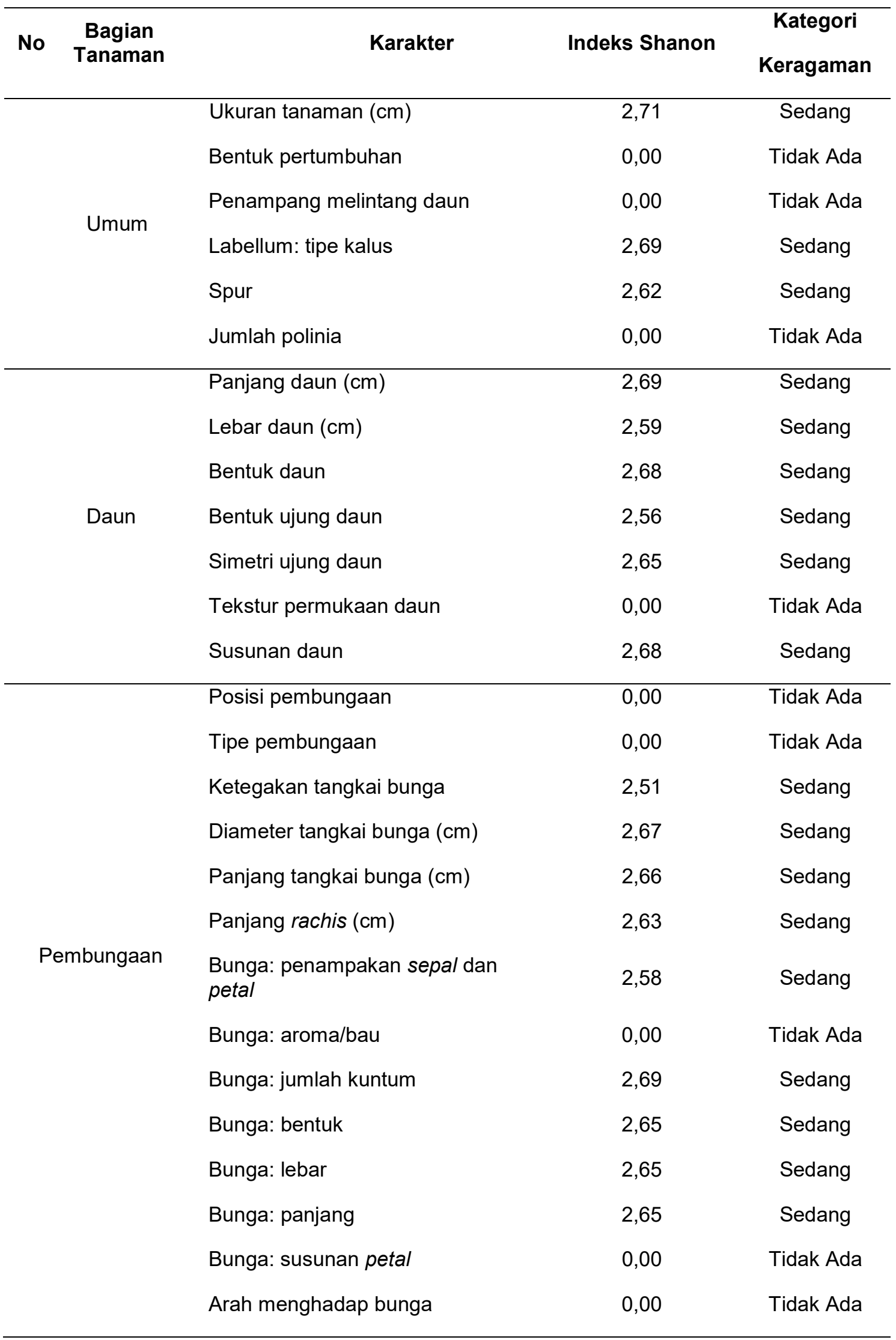


Rahmadani dan Purwantoro / Vegetalika. 2020. 9(4): 535-546

Lanjutan Tabel 1. Indeks Shanon Phalaenopsis spesies dan hybrid

\begin{tabular}{|c|c|c|c|}
\hline & Panjang braktea & 2,67 & Sedang \\
\hline \multirow[t]{5}{*}{ Pembungaan } & Bentuk braktea & 2,65 & Sedang \\
\hline & Resupinasi & 0,00 & Tidak Ada \\
\hline & Bentuk sepal & 2,60 & Sedang \\
\hline & Panjang sepal & 2,64 & Sedang \\
\hline & Lebar sepal & 2,57 & Sedang \\
\hline \multirow[t]{7}{*}{ Sepal } & Bentuk ujung sepal & 2,54 & Sedang \\
\hline & Penampang melintang sepal & 2,67 & Sedang \\
\hline & Dorsal sepal: corak warna & 2,56 & Sedang \\
\hline & Lateral sepal: corak warna & 2,54 & Sedang \\
\hline & Bentuk petal & 2,64 & Sedang \\
\hline & Panjang petal & 2,56 & Sedang \\
\hline & Lebar petal & 2,45 & Sedang \\
\hline \multirow[t]{9}{*}{ Petal } & Bentuk ujung petal & 2,42 & Sedang \\
\hline & Penampang melintang petal & 2,58 & Sedang \\
\hline & Petal: jumlah warna & 2,66 & Sedang \\
\hline & Petal: corak warna & 2,55 & Sedang \\
\hline & Bentuk keping tengah & 2,62 & Sedang \\
\hline & Panjang keping tengah & 2,66 & Sedang \\
\hline & Lebar keping tengah & 2,59 & Sedang \\
\hline & Penampang melintang labellum & 2,67 & Sedang \\
\hline & Letak lekuk bibir & 2,68 & Sedang \\
\hline \multirow[t]{6}{*}{ Labellum } & Ada tidaknya keping sisi & 0,00 & Tidak Ada \\
\hline & Bentuk keping sisi & 2,67 & Sedang \\
\hline & Kulvatur keping sisi & 2,66 & Sedang \\
\hline & $\begin{array}{l}\text { Tonjolan atau kerutan pada keping } \\
\text { tengah }\end{array}$ & 2,57 & Sedang \\
\hline & Corak keping tengah & 2,44 & Sedang \\
\hline & Corak keping sisi & 2,51 & Sedang \\
\hline
\end{tabular}


Indeks Shanon Phalaenopsis spesies dan hyrid (tabel 1) menunjukkan semua sub karakter pengamatan memiliki nilai Indeks Shanon dibawah 3,00 yang termasuk dalam tingkat keragaman sedang. Pada karakter umum, nilai Indeks Shanon pada sub karakternya berkisar dari 2,62-2,71 yang diklasifikasikan pada tingkat keragaman sedang, dan nilai Indeks Shanon sebesar 0,00 menunjukkan tidak ada keragaman sub karakter pada anggrek yang diamati. Nilai Indeks Shanon sebesar 0,00 pada Phalaenopsis juga dapat menunjukkan kategori pada sub karakter tertentu yang sifatnya akan selalu muncul pada setiap tanaman. Pada karakter daun, nilai Indeks Shanon pada sub karakternya berkisar dari 2,56-2,69 yang diklasifikasikan pada tingkat keragaman sedang dan nilai Indeks Shanon sebesar 0,00 pada sub karakter permukaan daun yang menunjukkan tidak ada keragaman. Pada karakter pembungaan memiliki nilai Indeks Shanon berkisar 2,51-2,69 yang berarti tingkat keragamannya sedang, dan nilai Indeks Shanon sebesar 0,00 menunjukkan tidak ada keragaman. Pada karakter sepal dan petal memiliki nilai Indeks Shanon berkisar 2,42-2,67 yang termasuk dalam tingkat keragaman sedang. Pada karakter labellum memiliki nilai Indeks Shanon berkisar 2,44-2,67 yang diklasifikasikan pada tingkat keragaman sedang. Selanjutnya, nilai Indeks Shanon untuk karakter secara keseluruhan Phalaenopsis spesies dan hybrid sebesar 2,70. Hal ini menunjukkan bahwa tingkat keragaman anggrek Phalaenopsis untuk semua karakter tergolong sedang.

\section{Analisis Kekerabatan Phalaenopsis spesies dan hybrid}

Pada penelitian ini, hubungan kekerabatan hanya didasarkan pada karakter kualitatif. Hal ini dikarenakan sampel yang digunakan terbatas sehingga diambil dari berbagai lokasi dengan teknik budidaya dan perawatan anggrek yang berbeda pula sehingga faktor lingkungan sangat mempengaruhi. Selain itu, sampel yang digunakan tidak ditanam serentak sehingga terdiri dari berbagai macam umur, akibatnya data kuantitatifnya dapat berubah. Menurut Ambarwati (2014), menyatakan bahwa sifat kualitatif dikendalikan oleh gen mayor, banyaknya gen pengendali monogenik dan oligenik sehingga gen pengendali jelas pengaruhnya. Selain itu, penentuan hubungan kekerabatan berdasarkan sifat kualitatif lebih efektif karena sifat ini tidak peka terhadap perubahan lingkungan sehingga sifat tersebut akan selalu muncul meskipun ditanam di lingkungan yang berbeda. Menurut Syukur et al. (2010), pemilihan tetua berdasarkan karakter kualitatif lebih mudah karena karakter tersebut hanya dikendalikan oleh sedikit gen sehingga perbedaan fenotip tetua dapat menunjukkan perbedaan gen sedangkan pemilihan tetua berdasarkan karakter kuantitatif sulit dilakukan karena karakter tersebut 
dikendalikan oleh banyak gen sehingga perbedaan fenotip atau morfolgi tidak bisa menggambarkan perbedaan genotipnya.

Tujuan dilakukan analisis kekerabatan adalah untuk mengetahui tingkat kekerabatan anggrek sehingga dapat menjadi informasi dalam menentukan tetua persilangan. Hubungan kekerabatan berdasarkan karakter kualiatitif ini, akan mempermudah pemulia dalam merancang fenotip anggrek yang diinginkan. Hubungan kekerabatan antar spesies anggrek baik dalam satu genus maupun beda genus dapat diketahui dari dendrogram. Dendogram tersebut dapat menunjukkan persentase kedekatan antar anggrek yang menggelompok berdasarkan kemiripan data fenotip yang ada. Pengelompokan berdasarkan data fenotip merupakan langkah awal yang digunakan untuk mengetahui hubungan kekerabatan antar spesies (Dwiatmini et al., 2003). Tingkat kemiripan antar anggrek ditunjukan oleh nilai similiaritasnya yang berkisar antara 0,00 sampai 1,00. Semakin tinggi nilai similaritasnya maka semakin tinggi kemiripan antar anggrek tersebut. Selain itu, pada dendogram dapat dilihat adanya beberapa sub klaster. Menurut Kartikaningrum et al. (2002) menyatakan bahwa anggrek alam yang berada pada kelompok yang sama menunjukkan kekerabatan dekat sehingga tingkat keberhasilan persilangan tinggi.

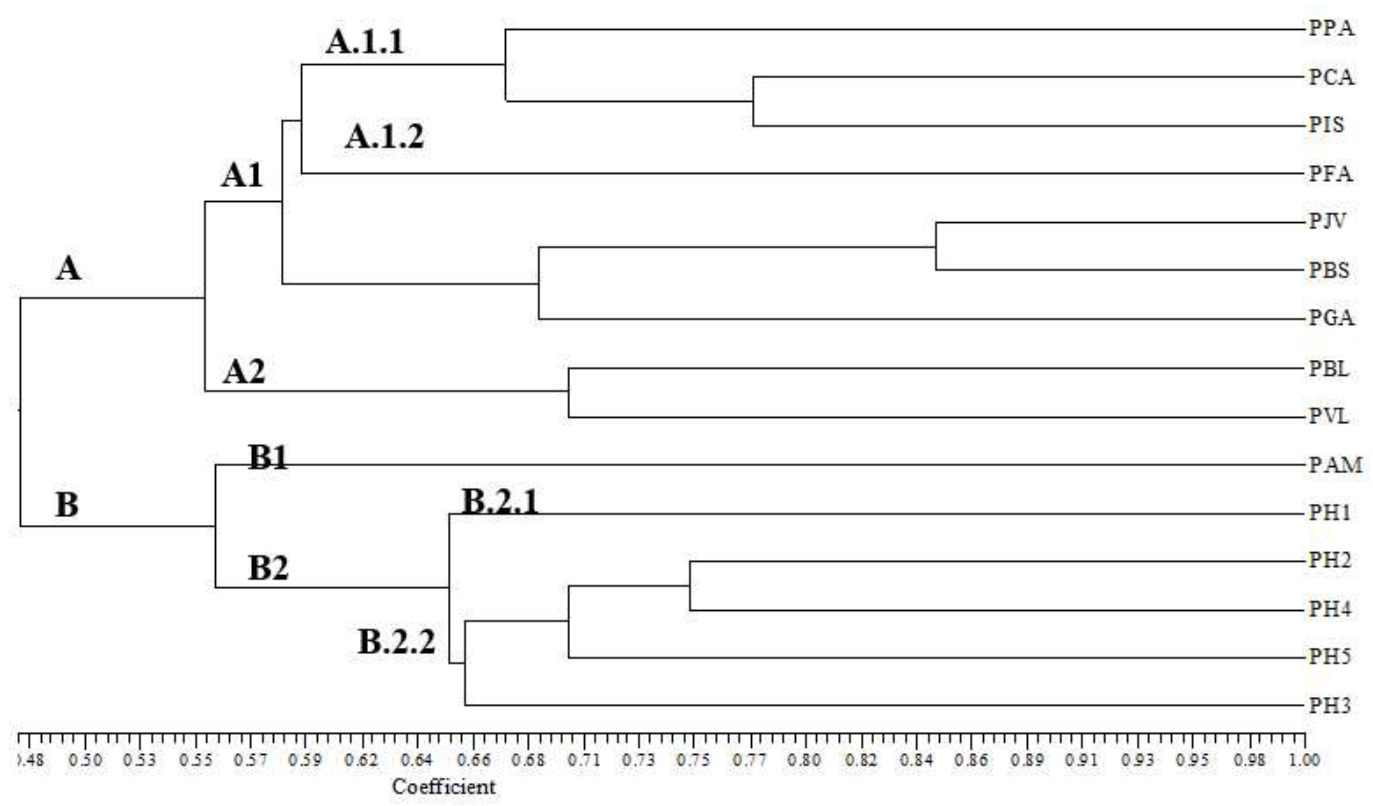

Gambar 1. Dendogram Phaelonopsis spesies dan hybrid

Berdasarkan dendogram tersebut diketahui bahwa terdapat dua klaster yaitu $\mathrm{A}$ dan $\mathrm{B}$ dengan koefesian kemiripin 0,48. Klaster A terdiri dari sembilan Phalaenopsis spesies dan klaster B terdiri dari semua Phal. hybrid dan Phal. amabilis. Berdasarkan pengamatan langsung di lapangan dapat dilihat jelas adanya perbedaan pada bentuk 
bunga antar klaster tersebut. Perbedaannya dapat dilihat dari bentuk petal dan ukuran petalnya yang mana semua anggrek pada klaster B memiliki petal berbentuk belah ketupat atau agak membulat dengan ukuran petal yang lebih besar dari pada sepalnya dalam satu bunga. Selain itu, pengelompokkan klaster ini juga berdasarkan bentuk ujung daun romping. Pengelompokkan ini dapat memberikan informasi bahwa kedekatan hubungan antara Phal. amabilis dan Phal. hybrid yang menandakan Phal. amabilis sering dijadikan sebagai salah satu tetua untuk menghasilkan anggrek hybrid. Menurut Tang dan Chen (2007), menyatakan jenis Phalaenopsis yang sering digunakan sebagai tetua untuk pengembangan varietas baru dibedakan atas dua kelompok yaitu bunga standar berukuran besar dan kelompok novelti. Kelompok bunga standar memiliki warna bunga putih, pink, ataupun bermotif sedangkan kelompok novelti memiliki bunga berukuran kecil, dengan warna beragam, jumlah bunga banyak dan beberapa menghasilkan aroma harum. Tetua dari kelompok bunga standar adalah Phal. amabilis dan Phal. schilleriana sedangkan novelti biasanya adalah Phal. violaceae, Phal. amboinensis, Phal. venosa, Phal. stuartiana, dan Phal. equestris.

Klaster A terbagi menjadi dua kelompok yaitu sub klaster A1 dan A2 dengan nilai similaritas sebesar 0,56. Klaster A2 merupakan Phal. belina dan Phal. violacea yang memiliki karakter yang berbeda dengan anggrek klaster A1 yaitu tangkai bunga termasuk ke dalam kategori semi tegak, bentuk ujung sepal meruncing dengan sisi yang tajam, bentuk keping tengah bulat, dan penampang melintang labellum datar. Pada kelompok sub klater A1 menggelompok menjadi sub sub klaster A1.1 dan A.1.2 pada nilai similaritas sebesar 0,58. Sub sub klaster A1.2 merupakan Phal. javanica, Phal. gigantea, dan Phal. Amboinensis yang memiliki bentuk bunga bulat, bentuk ujung sepal suntih dangkal bertulang runcing, bentuk sepal bulat telur, bentuk petal jorong, dan bentuk keping sisi tipe II. Klaster B terbagi menjadi dua kelompok yaitu sub kluster B1 dan B2 dengan nilai similaritas sebesar 0,56. Pengelompokkan ini berdasarkan pada karakter bentuk sepal dan penampang melintang sepal. Sub klaster B1 adalah Phal. amabilis yang memiliki bentuk sepal kategori lonjong dengan penampang sepalnya datar. Penelitian lain menyebutkan karakterisasi yang dilakukan pada daun dan bunga Phal. amabilis dengan Phal. hybrid membentuk dua kelompok dengan nilai similaritas sebesar 0,53 sedangkan semua Phal. hybrid mengelompok berdasarkan nilai similaritas sebesar 0,73 (Pangestu et al., 2014). Perbedaan nilai similaritas ini tergantung pada karakter dan jumlah sub karakter pengamatan. Semakin banyak karakter dan individu yang diamati maka semakin banyak penanda morfologinya sehingga data yang diperoleh semakin akurat. 


\section{KESIMPULAN}

1. Nilai Indeks Shanon pada Phaelonopsis spesies dan hybrid sebesar 2,70 yang menunjukkan tingkat keragamannya sedang.

2. Hubungan kekerabatan pada Phalaenopsis spesies dan hybrid membentuk dua klaster yaitu A dan B dengan nilai similaritasnya 0,48.

\section{DAFTAR PUSTAKA}

Ambarwati, E. 2014. Pengantar Genetika Kuantitatif. Gadjah Mada University Press, Yogyakarta.

Balithi (Balai Penelitian Tanaman Hias). 2007. Panduan Karakterisasi Tanaman Anggrek. Pusat penelitian dan pengembangan hortikultura, Badan penelitian dan pengembangan pertanian, Jakarta.

Dwiatmini, K., Mattjik, N.A. Aswidinnoor, dan N.L.T. Matius. 2003. Analisis pengelompokan dan hubungan kekerabatan spesies anggrek Phalaenopsis berdasarkan kunci determinasi fenotipik dan marka molekuler RAPD. Jurnal Holtikultura 13: 16-27.

Fachrul, M. F. 2008. Metode Sampling Bioekologi. Bumi Aksara, Jakarta.

Hardiyanto, E. Mujiarto, dan E.S. Sulasmi. 2007. Kekerabatan genetic beberapa spesies jeruk berdasarkan taksonometri. Journal Hortikultura 17: 203-216.

Hartati, S dan L. Darsana. 2015. Karakterisasi anggrek alam secara morfologi dalam rangka pelestarian plasma nutfah. J. Agron. Indonesia 43: 133 - 139.

Kartikaningrum, S., N. Hermiati, A. Baihaki. 2002. Kekerabatan antar genus anggrek berdasarkan data fenotip. Zuriat 13: 1-10.

Niknejad, A., M.A. Kadir, S.B. Kadzimin, N.A.P. Abdullah, dan K. Sorkheh. 2009. Moleculer characterization and phylogenetic relationship among and within species of Phalaenopsis (Epdendroideae: Orchidaceae) base on RAPD analysis. Afr. J. Biotech 8: 5225-5240.

Pangestu, F., S. A. Aziz, dan D. Sukma. 2014. Karakterisasi Morfologi Anggrek Phalaenopsis. J. Hort. Indonesia 5: 29-35.

Parnata, A. S. 2005. Panduan Budi Daya dan Perawatan Anggrek. Argo Media Pustaka, Jakarta.

Purwantoro, A., E. Ambarwati, dan F. Setyaningsih. 2005. Kekerabatan antar anggrek spesies berdasarkan sifat morfologi tanaman dan bunga. IImu Pertanian.12: 111.

Syukur, M., S. Sujiprihati, dan R. Yunianti. 2012. Teknik Pemuliaan Tanaman. Penebar Swadaya, Jakarta. 
Tang, C.Y., dan W.H., Chen. 2007. Breeding and Development of New Varieties in Phalaenopsis. In WH Chen and HH Chen. Orchid Biotechnology. World Scientific Pub 1: 1-15 